\title{
Diagnostic delay in cystic fibrosis: lessons from newborn screening
}

\author{
B WILCKEN, S J TOWNS, AND C M MELLIS \\ Oliver Latham Laboratory, New South Wales Department of Health, and the Department of Respiratory \\ Medicine, Royal Alexandra Hospital for Children, Camperdown, Australia
}

SUMmARY Newborn screening for cystic fibrosis (CF) by dried blood spot immunoreactive trypsin (IRT) assay is now feasible, but the benefits are disputed. We have studied the symptoms and signs at diagnosis in 48 babies detected during a newborn screening programme, and also the delay between presentation with symptoms and diagnosis in all 33 babies diagnosed at our CF clinic in the two years before screening began. Eleven of the 48 screened babies had meconium ileus, 16 had gastrointestinal symptoms only, and 14 had both respiratory and gastrointestinal symptoms at the time of diagnosis. Five of the remaining 7 babies developed clear cut symptoms or signs soon after diagnosis. Thus, $96 \%$ (46 of 48) of the babies had symptoms by 3 months of age. Of the 33 infants diagnosed clinically in the two years immediately before screening, $13(39 \%)$ were over 12 months of age at diagnosis. Moreover, the mean delay between presentation with symptoms and diagnosis of CF in these infants was $2 \cdot 6$ years. Our data show that the delay between onset of symptoms and diagnosis is far greater than previously supposed and that most babies detected by our screening programme already had symptoms that warranted treatment at the time of their diagnosis.

While it has been taken for granted that the earlier a child with symptoms of cystic fibrosis (CF) is treated the better the prognosis, ${ }^{12}$ there is no agreement on whether very early diagnosis by newborn screening followed by prophylactic treatment confers any extra benefit. $^{34}$ Early diagnosis by screening would obviously facilitate prompt, aggressive treatment of respiratory or gastrointestinal symptoms, or both, as soon as they arise. The delay between the onset of symptoms and clinical diagnosis of $\mathrm{CF}$ has been examined in 33 new patients presenting at a large CF clinic during 1980 and 1981 . The natural history of the disorder during the first weeks of life has also been studied in 48 patients diagnosed by newborn screening in 1981-3.

\section{Patients and methods}

Patients diagnosed clinically in the two years before newborn screening started. All 33 patients with CF diagnosed at this hospital in the two years before neonatal screening was started were included. The parents of the children were interviewed on one or more occasions by one of us (SJT). Case notes were consulted and the following information recorded: the age of the patient at diagnosis; age of initial presentation to medical attention; the mode of presentation (meconium ileus, sibling of a CF patient, or with symptoms, namely, failure to thrive, gastrointestinal, respiratory, and combined gastrointestinal plus respiratory symptoms); the number of visits to a medical practitioner; and the number of hospital admissions, before diagnosis. The babies were grouped according to age at diagnosis as follows: group 1-before 2 months of age; group 2 -between 2 months and 12 months; group 3later than 12 months of age.

Patients diagnosed by newborn screening. One hundred and twenty thousand infants were screened for CF by blood spot immunoreactive trypsin (IRT) assay $^{5}$ as part of a state wide screening programme, and 50 babies with $\mathrm{CF}$ are known to have been born during this period. Forty eight babies had a positive screening test. One baby was accidentally not screened because of severe illness (small bowel atresia) and another was missed by the screen but diagnosed at 8 weeks with severe failure to thrive and bronchiolitis. The first 35 infants detected with cystic fibrosis have been reported previously, together with details of the methods. ${ }^{6}$ 


\section{Results}

\section{Patients diagnosed clinically.}

Group 1 comprised 11 patients diagnosed before two months of age. Five of these had meconium ileus, one had meconium plug syndrome, and three had a close relative with $\mathrm{CF}$. Although a definitive diagnosis by sweat test was not made in these babies until up to 8 weeks of age, the possibility of CF had been discussed with the parents during the first week of life. The remaining two patients in this group had symptoms-one had two admissions to hospital with pneumonia before diagnosis at 6 weeks, and one failed to thrive from the age of two weeks and had three medical consultations before the diagnosis was established at 7 weeks.

Group 2 comprised 9 patients diagnosed between 2 and 12 months of age. The average age of presentation was 1.9 months, and the average age at diagnosis was 5.7 months. The commonest mode of presentation in this group was failure to thrive, usually with obvious gastrointestinal symptoms. Details of these 9 patients are shown in Table 1.

Group 3 comprised 13 patients (39\% of the total) in whom a diagnosis of CF was not made until after 12 months of age. Most had respiratory symptoms, usually in association with gastrointestinal symptoms. The patient details are summarised in Table 2. The mean delay between presentation with symptoms and diagnosis was 2.6 years in this group.

In all of these 33 patients whose newborn screening blood sample could be retrieved from our records and tested, the IRT value was raised above that of control samples. ${ }^{6}$

Babies diagnosed during the newborn screening period. Forty eight babies had a positive screening test. Notification of a raised IRT value on the second blood sample and request for sweat test was made usually between 3 and 6 weeks of age, and by 8 weeks in all but two babies. The mean age at diagnosis was 37 days.

Table 1 Patients aged over 2 months and under 12 months at the time of diagnosis

\begin{tabular}{|c|c|c|c|c|c|}
\hline Case No & $\begin{array}{l}\text { Age at diagnosis } \\
\text { (mths) }\end{array}$ & $\begin{array}{l}\text { Age at first } \\
\text { presentation }\end{array}$ & $\begin{array}{l}\text { Symptoms at } \\
\text { presentation* }\end{array}$ & $\begin{array}{l}\text { Visits to doctor before } \\
\text { diagnosis }(\mathrm{No})\end{array}$ & $\begin{array}{l}\text { Hospital admissions } \\
\text { before diagnosis }(\mathrm{No})\end{array}$ \\
\hline 1 & $5 \cdot 5$ & 3 mths & Respiratory & 2 & 1 \\
\hline 2 & 3 & 5 dys & FTT/GIT respiratory & 5 & 1 \\
\hline 3 & 8 & $6 \mathrm{mths}$ & FTT/GIT & 5 & $i$ \\
\hline 4 & 11 & $3 \frac{1}{2}$ mths & FTT/GIT, respiratory & 10 & - \\
\hline 5 & 6 & birth $\dagger$ & FTT/GIT & 3 & 2 \\
\hline 6 & 4 & 3 wks & FTT/GIT & 9 & 2 \\
\hline 7 & 7 & 3 mths & FTT/GIT, respiratory & 3 & 1 \\
\hline 8 & 3 & 3 wks & FTT/GIT & 2 & 2 \\
\hline 9 & 4 & 3 wks & GIT & 3 & 1 \\
\hline
\end{tabular}

*First listed is major mode of presentation.

†Congenital hydrocephalus, Erb's palsy noted at birth -2 previous admissions for VP shunting.

FTT = failure to thrive; GIT = gastrointestinal.

Table 2 Patients aged 12 months and over at the time of diagnosis

\begin{tabular}{|c|c|c|c|c|c|}
\hline Case No & $\begin{array}{l}\text { Age at } \\
\text { diagnosis (yrs) }\end{array}$ & $\begin{array}{l}\text { Age at first } \\
\text { presentation }\end{array}$ & $\begin{array}{l}\text { Symptoms at } \\
\text { presentation }\end{array}$ & $\begin{array}{l}\text { Visits to doctor before } \\
\text { diagnosis }(\mathrm{No})\end{array}$ & $\begin{array}{l}\text { Hospital admissions } \\
\text { before diagnosis }(\mathrm{No})\end{array}$ \\
\hline 1 & $3 \cdot 5$ & $1 \cdot 5 \mathrm{yrs}$ & Rectal prolapse & 5 & - \\
\hline 2 & $1 \cdot 3$ & $1 \mathrm{yr}$ & Rectal prolapse, resp & 6 & 1 \\
\hline 3 & $2 \cdot 3$ & 9 mths & GIT resp & 12 & 2 \\
\hline 4 & $2 \cdot 5$ & 4 mths & FTT, resp & 14 & - \\
\hline 5 & $1 \cdot 3$ & Birth & FTT & 10 & 一 \\
\hline 6 & $1 \cdot 1$ & $3 \mathrm{mths}$ & FTT/GIT, resp & 14 & 1 \\
\hline 7 & 4 & $5 \mathrm{mths}$ & Resp & 13 & 1 \\
\hline 8 & 3 & 6 wks & Resp & 26 & 3 \\
\hline 9 & $2 \cdot 5$ & 3 mths & GIT, resp & 6 & 4 \\
\hline 10 & $3 \cdot 5$ & 2 mths & GIT, resp & 10 & 8 \\
\hline 11 & $4 \cdot 2$ & $1 \mathrm{yr}$ & $\begin{array}{l}\text { Relative with CF, } \\
\text { GIT, resp }\end{array}$ & 30 & 2 \\
\hline 12 & 8 & 3 mths & $\begin{array}{l}\text { Sibling with CF, } \\
\text { GIT, resp }\end{array}$ & 72 & 2 \\
\hline 13 & $2 \cdot 5$ & 3 mths & $\begin{array}{l}\text { Sibling with CF, } \\
\text { GIT, resp }\end{array}$ & 4 & 一 \\
\hline
\end{tabular}

FTT = failure to thrive; GIT = gastrointestinal; Resp = respiratory. 
Table 3 Symptoms in 48 babies diagnosed by screening

\begin{tabular}{lll}
\hline Symptoms & $\begin{array}{l}\text { At diagnosis } \\
(3-8 \text { weeks }) \\
(N o)\end{array}$ & $\begin{array}{l}\text { At } 3 \text { months } \\
(N o)\end{array}$ \\
\hline Previous meconium ileus & 11 & 11 \\
Gastrointestinal & 16 & 19 \\
Gastrointestinal, respiratory & 14 & 14 \\
Respiratory & 0 & $2^{*}$ \\
Asymptomatic & 7 & 2
\end{tabular}

* Includes an asymptomatic baby with Staphylococcus aureus and Pseudomonas aeruginosa in pharyngeal aspirates (see text).

Eleven of the 48 babies presented in the neonatal period with meconium ileus. Thirty of the remaining 37 had gastrointestinal symptoms at the time of diagnosis. These symptoms ranged from severe failure to thrive, with weight loss and oedema to increased diarrhoea, with fat globules in the stools. Fourteen of these 30 babies also had pulmonary symptoms, although these were mild in 7. One baby with no pulmonary symptoms had an abnormal chest radiograph with right upper lobe collapse. No baby had pulmonary symptoms alone at this time. Only 7 babies had no symptoms at diagnosis, but four of these developed symptomsbronchitis in one, and a fall off in weight gain in three-soon afterwards. A fifth asymptomatic baby, upon his first visit to the clinic at two months, had Staphylococcus aureus and Pseudomonas aeruginosa cultured from a pharyngeal aspirate. (Table 3) Among those 30 babies with symptoms, the diagnosis of CF was only being considered in four, three of whom had siblings with known CF.

\section{Discussion}

Our report of the age pattern at diagnosis of CF in patients before the screening programme started is similar to findings in other Australian states and in other countries. In Victoria, between 1955 and 1978, $32 \%$ of all CF patients were over the age of 12 months at diagnosis. ${ }^{4}$ In $1979-82$ in Victoria, $43 \%$ of patients were diagnosed under 3 months of age, but $35 \%$ were older than 12 months (personal communication). In South Australia, between 1977 and $1981,40 \%$ of patients were under 3 months of age and $43 \%$ older than 12 months at diagnosis (personal communication). Gitzelmann reports that in Switzerland, where clinical awareness is traditionally high, approximately $30 \%$ of cases remain undiagnosed at 12 months. ${ }^{2}$ A figure of $35 \%$ has been reported for East Germany ${ }^{7}$ and $40 \%$ for Canada. ${ }^{8}$ One comprehensive report from the United States shows, however, that at least $52 \%$ of patients remained undiagnosed at 12 months of age. ${ }^{9}$

During the period of screening in New South Wales, it is likely that most of the cases were identified and only one child is known to have been missed by the screen. The incidence of CF detected during this period was $1 / 2400$, which is close to the expected incidence. ${ }^{10}$ At the time of diagnosis, $85 \%$ of the screened babies already had symptoms or signs of CF, and by 3 months of age this figure was $96 \%$. These findings indicate that the usual delay between onset of symptoms and diagnosis is far greater than that suggested by retrospective enquiry.

Now that screening for CF is feasible, with acceptably low false positive and false negative rates, ${ }^{6}$ it is important that controlled studies be undertaken to investigate its value. In the meantime, our study has important implications for screeningparticularly in light of the high incidence of CF symptoms at such an early age. It is not clear at present when to start treatment of CF. Nevertheless, once there are respiratory or gastrointestinal symptoms, or signs of the disease, appropriate treatment must be offered. Our investigation shows that without screening there are appreciable delays between onset of symptoms and diagnosis. The data from the group of screened babies suggest that these delays are far more substantial than previously suspected; almost all babies had symptoms at 3 months. Hence, screening for CF may be justified not only in relation to prophylactic treatment, the benefit of which is disputed, but also to facilitate early and aggressive treatment of mild symptoms, which is not at present being achieved.

We thank Dr $\mathbf{J}$ Brown and the many other paediatricians who supplied information about their patients, Mr A R D Brown and staff members at the Oliver Latham Laboratory who performed the screening assays, and Mrs E Pluck and Mrs S Morven for secretarial assistance.

\section{References}

1 Nadler HL, Girimaji JSR, Taussig LM. Cystic fibrosis. In: Stanbury JB, Wyngaarden JB, Fredrickson DS, eds. The metabolic basis of inherited disease. 4th edition. New York: McGraw-Hill, 1978:1683-710.

2 Gitzelmann R. Why we should not screen our newborn for cystic fibrosis. Helv Paediatr Acta 1981 ;36:493-4.

3 Dodge JA, Ryley HC. Screening for cystic fibrosis. Arch Dis Child 1982;57:774-80.

4 Phelan PD. Screening for cystic fibrosis (Commentary). Arch Dis Child 1982;57:779-80.

5 Crossley JR, Elliott RB, Smith PA. Dried-blood spot screening for cystic fibrosis in the newborn. Lancet $1979 ; \mathbf{i}: 472-4$.

6 Wilcken B, Brown ARD, Urwin R, Brown DA. Cystic fibrosis screening by dried blood spot trypsin assay: results in 75,000 newborn infants. $J$ Pediatr 1983;102: 383-7. 
7 Gottschalk B. Die mukoviszidose in der Deutschen Demoncratischen Republik. Deutsche Gesundheitwesen 1972;27:2292-5.

8 Nesbitt CJ, Gregg MB, Olmsted N, Pogue RE, Warwick WJ, Wood RE. 1976 report on survival studies of patients with cystic fibrosis. Atlanta Georgia; Cystic Fibrosis Foundation, 1978.

9 Warwick WJ. Undiagnosed patients with cystic fibrosis. J Chronic Dis 1980;33:685-96.
10 Allan JL, Robbie M, Phelan PD, Danks DM. The incidence and presentation of cystic fibrosis in Victoria, 1955-1978. Aust Paediatr J 1980;16:270-3.

Correspondence to $\mathrm{Dr}$ B Wilcken, Oliver Latham Laboratories, Macquarie Hospital, PO Box 169, North Ryde NSW 2113, Australia.

Received 30 June 1983

\section{Fifty years ago}

\section{Proceedings of the Sixth Annual General Meeting of the British Paediatric Association}

Dr Alan Moncrieff (London) suggested that in view of the recent persecution of Jewish paediatricians in Germany members should, as far as possible, find temporary posts for some of them in this country until things became more settled there.

Archives of Disease in Childhood 1933; 8: 361.

(A future editor of the Archives and inaugural professor of child health at the Institute of Child Health, London, speaks up in the year of his election to the British Paediatric Association. 1933 was pretty quick off the mark on this topic. Philip Evans).

Studies in the anaemias of infancy and early childhood Part IV. The Haemolytic (erythronoclastic) anaemias of the neonatal period with special reference to erythroblastosis of the newborn

LEONARD G PARSONS, J C HAWKSLEY AND ROBERT GITTINS (Birmingham)

Haemolysis occurs constantly in intra- and extra- uterine life but normally is kept within bounds by some mechanism. Hampson has suggested that haemolysis may be controlled in intrauterine life by something produced by the mother and passed on by her to the fetus, which in extrauterine life is elaborated by the infant itself; for at birth a considerable degree of haemolysis occurs owing to alterations in the oxygen tension of its surroundings, which is prevented from becoming excessive by the anti-haemolytic agent. If this factor is absent or insufficient, excessive haemolysis with the production of anaemia and perhaps severe jaundice may occur; this may however, be prevented if the anti-haemolytic factor is given by administration of blood serum. This is the basis of the treatment of icterus gravis by injections of blood serum, a treatment which we owe to Hampson and which has proved a great success ... Such an hypothesis would furnish an adequate explanation for the fact that jaundice is more frequent and severe in preterm than term children; also of the development of haemolytic anaemia in the preterm and of its prevention by blood transfusion ... It . . . fails adequately to explain hydrops fetalis and those cases of icterus gravis which develop spastic diplegia in later life and those which show necrotic changes in the liver.

Archives of Disease in Childhood 1933; 8: 159-183.

(Rhesus incompatibility not then recognised. The history of an error; the Hampson hypothesis was false and the treatment by injection of maternal serum directly wrong. Philip Evans). 